CPE

4,2

186

Received 28 June 2021 Revised 28 June 2021 Accepted 28 June 2021

\section{Critical examination and source-tracing in China of economic thought of Francois Quesnay from the perspective of the construction of socialist political economics with Chinese characteristics}

\author{
Xu Zhang \\ Institute of Economics, Chinese Academy of Social Sciences, Beijing, China, and \\ Tianjiao Wang \\ School of Marxism Studies, Renmin University of China, Beijing, China
}

\begin{abstract}
Purpose - Francois Quesnay, known as the "Confucius of Europe", was profoundly influenced by traditional Chinese culture to form his thoughts, which contained strong Chinese characteristics. This paper aims to examine economic thought of Francois Quesnay from the perspective of the construction of socialist political economics with Chinese characteristics.

Design/methodology/approach - Moreover, his thoughts also profoundly influenced subsequent economists, such as Adam Smith and Karl Marx. It can be said that Francois Quesnay was at the intersection of Chinese, Western and Marxist thought systems, so it is quite important to examine his thoughts critically and conduct source-tracing in China.

Findings - Hence, in the process of constructing and developing socialist political economy with Chinese characteristics, there is an urgent need to focus on exploring the value of excellent traditional Chinese culture at the theoretical level and combining the development and dissemination of the history of thoughts and the historical position of Chinese reality to realize the innovation and development of socialist political economy with Chinese characteristics.

Originality/value - Meanwhile, while absorbing nutrition from excellent traditional Chinese culture, it is necessary to establish scientific coordinates rather than use the discourse systems and paradigms of Western economics to interpret ancient Chinese economic thoughts. It is necessary to adhere to, inherit and develop Marxist political economy and absorb nutrition from Chinese excellent traditional culture to construct socialist political economy with Chinese characteristics.
\end{abstract}

Keywords Socialist political economics with Chinese characteristics, Economic thought of Francois Quesnay, Laissez-faire

Paper type Research paper

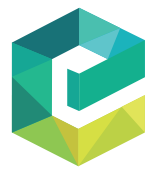

China Political Economy Vol. 4 No. 2, 2021 pp. $186-200$ Emerald Publishing Limited 2516-1652 DOI 10.1108/CPE-06-2021-0007
(C) Contemporary Economic Research. Published in China Political Economy. Published by Emerald Publishing Limited. This article is published under the Creative Commons Attribution (CC BY 4.0) licence. Anyone may reproduce, distribute, translate and create derivative works of this article (for both commercial and non-commercial purposes), subject to full attribution to the original publication and authors. The full terms of this licence may be seen at http://creativecommons.org/licences/by/4.0/ legalcode. Originally published in Simplified Chinese in Contemporary Economic Research.

Funding: This paper received funding from the Beijing Advanced Innovation Center for Teaching and Research on the Course of Ideological and Political Theory (grant agreement No. 19GJJB01). 
General Secretary Xi Jinping stated that philosophy and social sciences with Chinese characteristics should embody inheritance and nationality. To construct philosophy and social sciences with Chinese characteristics, people should find the best way to integrate various resources at all times and in all countries, especially from the following three areas: first, the resources of Marxism, including the basic principles of Marxism, the results of the Sinicization of Marxism and its cultural formation; second, the resources of excellent traditional Chinese culture, which are very precious and rare for developing philosophy and social sciences with Chinese characteristics; third, the resources of foreign philosophy and social sciences, including the achievements of philosophy and social sciences in all countries around the world, beneficial for enriching philosophy and social sciences with Chinese characteristics (The CPC Central Committee and the State Council, 2018, p. 322). These three theoretical resources should be absorbed, learned from and integrated with continuous innovation and development to construct the socialist political economics with Chinese characteristics.

Francois Quesnay, known as the "Confucius of Europe", was one of the enlightenment thinkers advocating learning Chinese philosophy and culture. The formation of his thoughts was profoundly influenced by traditional Chinese culture, which contained strong Chinese characteristics. Moreover, the path toward the formation of his thoughts also profoundly influenced the subsequent economists, such as Adam Smith and Karl Marx. In order to learn from and absorb rational elements of foreign economic thoughts and excellent traditional Chinese culture to construct the socialist political economics with Chinese characteristics, the critical examination and source-tracing in China of economic thought of Francois Quesnay can serve as a good example.

\section{The Chinese origin and duality of Quesnay's physiocratic economic thought system}

Karl Marx highly valued the economic thoughts of physiocrats represented by Francois Quesnay. Marx (1972) believed that "the analysis of capital, within the bourgeois horizon, is essentially the work of the Physiocrats. It is this service that makes them the true fathers of modern political economics" (p. 15) Quesnay, hailed as the "Confucius of Europe" then, was not only the originator and important representative of French physiocrats and one of the founders of classical political economics but also a scholar profoundly influenced by Chinese ideology. During the 100 years from the late 17th century to the late 18th century, an unprecedented "Chinese fever" swept through Europe, where Quesnay was one of the enlightenment thinkers who advocated learning Chinese philosophy and culture. The concept of "natural order" (basic law of natural movement) is the philosophical foundation of the system of the physiocratic economic thoughts founded by Quesnay. The term "physiocracy" originally meant the rule of nature. Likewise, the philosophical idea that supports the ancient Chinese economic thought can also be traced back to the "law of nature" of Taoist thought. Some scholars believed that Quesnay's thought of "natural order" was derived from his understanding of the concepts - "the way of heaven and Earth", "heavenly principle", and "Tao modeling itself after Nature" in ancient Chinese philosophy, and they conducted textual research. The two, though related to some extent, are not entirely equated. The physiocratic theory based on the "natural order" thought and the ancient Chinese economic thought based on the Taoist "law of nature" presented distinctly different characteristics. Compared with the physiocrats, who based their analysis on the natural process of agricultural production, ancient Chinese scholars paid more attention to extracting and establishing their own economic theories from policy practice.

Both Chinese and Western scholars affirmed that Chinese thought had a huge influence on the formation of Quesnay's physiocratic system. Quesnay's high regard for ancient Chinese culture and his admiration for Confucius, the representative of Confucianism, was commented 
$\mathrm{CPE}$

4,2

188 on at his funeral by his disciple, Victor Riqueti, marquis de Mirabeau as follows: "The whole teaching of Confucius aimed at restoring to human nature that first radiance, that first beauty, which it had received from Heaven, and which had become obscured by ignorance and passion. He, therefore, exhorted his countrymen to obey the Lord of Heaven, to honor and fear him, to love their neighbors as themselves, to overcome their inclinations, never to make passion the measure of action, but rather to subject it to reason, and not to do, or think, or say, anything contrary to reason. It would be impossible to add anything to this splendid diadem of religious morality, but the most essential part still remained to be done to bind it upon the brows of Earth; and this was the work of our master, whose keen ear caught from the lips of our common mother Nature the secret of the net product" (Reichwein, 1962, p. 92). Two points can be drawn from Mirabeau's summative comments on Quesnay's academic thoughts. First, Quesnay's ideological system was indeed profoundly influenced by Chinese philosophical thought. He had a deep understanding of Chinese philosophy and culture, especially Confucian thought, which he thought highly of. Second, Quesnay's ideological system was not entirely dependent on Chinese philosophical thought - Quesnay also proposed many original theories. For example, "Net product", a core category established by Quesnay in his physiocratic system, never appeared in Confucius' doctrine nor did it show up in other Chinese thoughts.

Analysis of the chronology of Quesnay's works indicates that Quesnay's absorption of Chinese philosophy was a gradual process. Based on French rationalism and natural law philosophy, Quesnay absorbed and accepted ancient Chinese philosophical thought, further constructed his theory of "natural order" and combined this theory with economic theory. Quesnay's works from 1756 to 1758, such as Évidence (Evidence), Fermiers (Farmers), Grains and Tableau économique (Economic Table) (Quesnay, 1980, pp. 4-9), showed that his thought in this period was profoundly influenced by Descartes and Spinoza's materialistic rationalism in the French philosophical circle, while Chinese thought neither impacted on his then economic theory system directly nor facilitated the formation of his theory, "natural order". In 1763, in Chapter VII of Mirabeau's Philosophie rurale (Rural Philosophy), Quesnay first proposed the concept of "natural order", a preliminary exploration of establishing a philosophical foundation for his economic thought (Quesnay, 1980, p. 266). From Quesnay's works, it can be inferred that his naturalistic ideas at this stage came from the ideas of French Enlightenment and Descartes's rationalism only (Hayek, 1967, pp. 106-121). In 1765, Quesnay published two works, Le droit naturel (On Natural Rights) and Le despotisme de la Chine (Despotism in China), which indicated that he had been profoundly influenced by ancient Chinese philosophical thoughts and established his own "natural order" theory based on French rationalism combined with Chinese philosophical thought. In Le despotisme de la Chine (Despotism in China), Quesnay (1992, p. 121) argued: "The laws that govern societies are the laws of natural order, the most advantageous to humankind. These laws form together what we call natural law: all men and all human powers ought to be controlled by these sovereign rules, instituted by the supreme being. They are immutable, irrefragable, and the best laws possible". In essential works such as Tableau économique avec son explication (Economic Table with its Explanations), Maximes générales du gouvernement économique d'un royaume agricole (General Maxims for the Economic Government of an Agricultural Kingdom) published after 1766, Quesnay had conclusively established the "natural order" theory as the philosophical basis of his physiocratic system.

In Le despotisme de la Chine (Despotism in China), a work dedicated to the study of the Chinese economy, society and culture, Quesnay (1992) introduced the core connotation of "natural law" as the foundation of Chinese philosophy and the development of Chinese agricultural economy in two subsections (pp. 45-65). Quesnay believed that China's prosperity and wealth were attributed to its "political and moral system established on the basis of, and as the result of, the knowledge of natural laws" (p. 111). Under such a system, "agriculture was always respected" (p. 67), the ruler set various laws and regulations and 
always granted various privileges to farmers to establish the concept of respecting farmers. In his early works Évidence (Evidence), Fermiers (Farmers), Grains and Tableau économique (Economic Table), Quesnay had already proposed the idea of physiocracy. In fact, after absorbing the essence of Chinese philosophical thought, Quesnay gradually deepened and perfected his preliminary thoughts on the "natural order" and physiocracy formed in the past. He hoped that France would learn from China, follow the law of nature and value agriculture.

Based on the thought of "natural order", the physiocratic ideological system built by Quesnay presented the feature of duality. On the one hand, while emphasizing the "natural order", Quesnay had an incomprehensive understanding of Taoist thought "wuwei" (nonintentional acting) as a "laissez-faire" concept, which was essentially a misinterpretation of Taoist thought. Lao Tzu's thought of "wuwei" and the subsequent economic thought of Sima Qian discussed in Shiji: Huozhiliezhuan (Records of the Grand Historian: Biography of Merchant), which was influenced by the theory of the Yellow Emperor and Lao Tzu (HuangLao theory), cannot simply be considered as economic thought consistent with Western liberalism. In Quesnay's early economic works, some liberal economic thoughts had taken shape. Subsequently, Quesnay drew on some beneficial elements from Chinese philosophy to deepen his liberalism and endowed a liberal core to the physiocratic school that he founded. This thought was further developed by Adam Smith and inherited by mainstream Western economics. On the other hand, Quesnay recognized the "natural order" as the objective law of economic and social development from the perspective of natural process of production and put forward the mission of understanding the objective law for economics, which is a remarkable scientific achievement of the physiocrats headed by Quesnay. In a sense, subsequent classical economists, such as Adam Smith and David Ricardo, all advanced along this path.

\subsection{Quesnay's interpretation of "wuwei erzhi" (achieving order and equilibrium without ruler's intervention) as "laissez-faire" is an issue of "intertranslatability" regarding translation in the history of thoughts}

It is generally believed that the term "libertarianism" used by Smith and other Englishspeaking scholars came from the French word "laissez-faire", and the traditional economic liberalism was created and first used by M. Gournay, a French physiocrat. Ludwig von Mises (1996, p. 730) once commented on the physiocratic thought founded by Quesnay, "In eighteenth-century France the saying laissez-faire, laissez-passer was the formula into which some of the champions of the cause of liberty compressed their program. They aimed to establish an unhampered market society. In order to attain this end, they advocated the abolition of all laws preventing more industrious and more efficient people from outdoing less industrious and less efficient competitors and restricting the mobility of commodities and of men." In fact, this term was coined by the French businessman Legendre in the 17th century. Jean Bodin Colbert, the Comptroller-General of Finances under Louis XIV, met with the businessman Legendre and asked him what the best way to protect French business was, and the latter answered, "laissez-faire, laissez-passer (let people do/make what they choose, let pass/go)." Pierre Boisguillebert, the founder of French classical political economics, was the first scholar who made it an academic term (Fu and Yan, 1995, p. 54).

In his early economic works, Quesnay had expressed some thoughts of economic liberalism. Quesnay (1980, p. 29) said in Fermiers (Farmers): "Freedom of external grain trade is an essential if not indispensable means to restore agriculture in the kingdom". In Grains, Quesnay took the impressive results achieved by Britain's free grain trade as an essential argument for his thought on free grain trade (Reichwein, 1962, p. 88). The Tableau économique (Economic Table) described by Quesnay (1980, p. 23) is essentially the analysis of a capitalist society established on private ownership, with complete freedom of economic activities and sufficient capital reserve required for the reproduction of wealth and the surplus production of the national economy. In the Tableau économique (Economic Table), 
CPE

4,2

190

Quesnay divided nationals into three sectors or, "classes" of people: the productive class (people in the agricultural sector), the proprietary class (landlords) and the sterile class (those in manufacturing and commerce). Moreover, he analyzed the production, circulation and reproduction activities among the three classes. Marx (1971, p. 269) pointed out: "Quesnay's Economic Table makes it clear by illustrating: how the annual total product of a country (actually France) circulates among the three classes and how it serves for the annual reproduction". According to Quesnay's analysis, the three classes kept the national economy in a state of equilibrium under a free economy with regular and cyclical reproduction of wealth every year. Marx (1972, p. 23) concluded that the physiocratic system "is in fact the first system which analyses capitalist production, and presents the conditions within which capital is produced, and within which capital produces, as eternal natural laws of production".

Many scholars attributed Quesnay's free economic thought to the influence of Chinese philosophical thought. Tan Min (1990), a Chinese scholar argued, "The physiocrats derived economic liberalism from the natural order and proposed the famous slogan 'laissez-faire', which was very similar to 'benefiting people in a way naturally gaining benefit among people" advocated by the ancient Chinese based on the concept of 'following the way of Heaven' or 'following the example of Heaven', and the political principle of 'acting nonintentionally (wuwei) and yet nothing left undone (wubuwei)'." Other scholars argued that Quesnay was influenced by Taoist thoughts, while the ideas in The Way of Lao Tzu: Tao Te Ching by Lao Tzu and Biography of Merchants by Sima Qian were the Taoist origins of "laissez-faire"; the market economy thought contained in Biography of Merchants and The Way of Lao Tzu: Tao Te Ching was even more profound than Smith and Quesnay in some respects (Liu et al., 2019). In Oriental Enlightenment: The Encounter between Asian and Western Thought, a book in the famous "trilogy of the history of ideas", the contemporary philosopher Clarke (2011) believed that the term "laissez-faire" used by physiocrats came from "wuwei", a Chinese Taoist concept." These views are rational in some way but not entirely accurate. Quesnay's early economic works suggested that he did not fully accept Chinese philosophical thought before and after he wrote the work Tableau économique (Economic Table). His liberalist thought, still at the embryonic stage and yet to form a mature theory, should only come from the French philosophy of natural law in this period. In 1765, Quesnay published Le despotisme de la Chine (Despotism in China), which indicated that he had already conducted in-depth studies of Chinese philosophy during this period. Influenced by Chinese philosophical thoughts, Quesnay sorted out, summarized and deepened his previous economic and philosophical thoughts from 1766 to 1767 and thus developed a relatively mature thought of liberalism. Quesnay made his comprehensive physiocratic thoughts clear in the three major works: Economic Table with its Explanations, Important Investigations and General Maxims for the Economic Government of an Agricultural Kingdom. Quesnay (1980, pp. 352-356) described in the Important Investigations: "In a prosperous country, the freedom and convenience of farming and trading have reached the highest stage." "Hence, foreign trade should be completely free, liberated from all constraints, exempt from all taxes". Quesnay pointed out the importance of free transaction and free trade to the economic prosperity and development of a country herein while proposing the idea of personal interests in harmony with the overall interests of society. "In all commercial transactions, sellers and buyers are opposed to each other, but they can enter into contracts based on their interests freely. Their adjusted interests are consistent with public interests because they themselves are the only right judges in their interests". This view was almost identical to Smith's theory that "an invisible hand" facilitated the alignment of private interests with public interest.

Most scholars who traced Quesnay's economic thought to Chinese Taoism, on the one hand, failed to pay attention to Quesnay's background of French naturalism philosophy; on 
the other hand, they also attributed Chinese Taoism to liberalism one-sidedly. Literally, the Taoist concept of "wuwei" tends to be interpreted as total inaction of the government. When this term was translated by Western missionaries, it was more clearly interpreted as the meaning of nonintervention by the government and absolute freedom of individuals subject to the influence of the Western context and cultural factors. However, in fact, the concept of "wuwei" must be understood in the Chinese context and the whole Taoist ideological system. It has different connotations under various conditions, different from the unrestrained freedom emphasized by "laissez-faire". It is not accurate to interpret "wuwei" as inaction in the literal sense and extend it to liberalism. The Taoist concepts of country governance expounded in Lao Tzu's The Way of Lao Tzu: Tao Te Ching and Sima Qian's Biography of Merchants are completely different from the "laissez-faire" economic policies of the Western countries. The practice of economic development has demonstrated that in the long history of mankind, the productivity of ancient China far surpassed that of the Western countries, but China, as deeply influenced by Lao Tzu and Taoism as it could be, has never formed a capitalist free-market economic system like the Western countries. Hence, Lao Tzu and Sima Qian cannot be simply regarded as the originators of market economy theory. Most scholars who classified Lao Tzu and Sima Qian as liberals actually categorized ancient Chinese philosophical and economic thoughts simply within the framework of the Western cultural context, without making an effort to explore the concepts such as "Tao modeling itself after Nature" and "wuwei" in the context of Chinese culture more deeply. Nor did they realize that the process of French physiocrats transforming the concept of "wuwei" into "laissez-faire" and interpreting "Tao modeling itself after Nature" as "Tao modeling itself after freedom" was a typical "intertranslatability" issue in the translation of intellectual history.

The issue of "intertranslatability" was raised by Liu He, one of the founders of the new translation theory. She points out that the failure to see the existence of "intertranslatability" in the study of modern intellectual history is a fatal blind spot (Liu, 2017, p. 1). The so-called "intertranslatability" refers to the epistemological space created when languages are mutually translated. In the translation between two languages, one word is often interpreted by multiple words, which cannot directly express the so-called concept. In this case, more thorough traceability work should be performed in the study of intellectual history. "Intertranslatability" has brought a major problem to the study of intellectual history, especially contemporary and modern history. It is also a fatal blind spot that cannot be bypassed in the study of intellectual history. It should be noted that intertranslatability is also a problem ignored by many scholars in their studies of the history of economic thoughts. From the perspective of Le despotisme de la Chine (Despotism in China), Quesnay's research on China was in-depth and detailed. However, due to the influence of context and cultural factors, some ancient Chinese philosophical thoughts in Quesnay's understanding had already been processed into new concepts under his specific thinking pattern. And the concepts of these new translated terms were distinctly different from the original Chinese thoughts. However, it is undeniable that these new concepts had a substantial influence on Quesnay's ideological system and enabled him to establish more mature liberalism. Tan (1990) once indicated that Quesnay's unique theory of the harmonious unity between laissezfaire and enlightened absolutism came from China because the state of laissez-faire under enlightened absolutism was unique to China and nonexistent in the Western world. This precisely reflected Quesnay's deviation in his understanding of the Taoist concept "wuwei". The sayings such as "people cultivate the land at sunrise and return home and rest at sunset; what's more, they dig a well to fetch drinking water and plant crops to get food. What an idyllic life! So, the throne is nothing to me" (Wang, 1990, p. 253), "If [the Lord] conducts governance through moral cultivation, the whole world will succumb to him with no intentional acting” (Zhu, 1983, p. 53), indicate that only by educating people with morals can a
Source-tracing in China 
CPE

4,2 ruler govern the country effectively, which is totally different from the laissez-faire thought of protecting private property rights emphasized by Western economics.

\subsection{Quesnay defined "natural order" as an objective law of economic development}

Quesnay started his analysis of the economy with the natural form of agricultural production. Quesnay's contribution was that in the Tableau économique (Economic Table), all elements related to the composition of an economic organization were abstractly explained, followed by the analysis of the relationship between various parts of this organization, the result of their interaction and the whole reproduction process of this organization (Quesnay, 1980, p. 266). Such analysis actually made it clear that there were objective laws independent of people's will in economic development. On this basis, Quesnay built his "net product" theory by calculating the difference between input and output in agricultural production. It was actually Quesnay's attempt to illustrate the source of surplus value by analyzing examples for the fact that the use value of output in agricultural production exceeded that of input, and the "net product" was also a "pure gift of nature" (Marx, 1972, p. 15). Quesnay found "net product" because in the observation of the changing forms of agricultural products as natural substances, he noticed that there was still surplus after deducting seeds and rations of agricultural laborers and tenant farmers. However, since Quesnay failed to establish a scientific theory of value, his theory was evidently incorrect. He ignored the consumption of other materials such as farm tools and fertilizers in agricultural production and failed to identify the unit of measurement for these other materials and agricultural products. Hence, he could only understand "net product" materially, not in terms of value.

In 1763, Mirabeau published a three-volume Philosophie rurale (Rural Philosophy). Quesnay guided him in the composition of the whole book and personally wrote the most important Chapter VII. The significance of this work lies not only in its great contribution to the popularization of Quesnay's economic theory but also in the preliminary exploration of the philosophical basis for establishing the "natural order" of the physiocratic school. According to Quesnay (1980, pp. 266-267), in the Tableau économique (Economic Table), he eliminated all the results from irregular intervention so as to "seek the natural order of causes and effects". The whole process of the reproduction movement of economic institutions is "the regeneration and continuity of the works of nature, the result of cohesion and concentration of its great forces". Quesnay attributed this process to the natural law: "The order and course of this amazing institution are eventually determined by the Creator. The great laws that prescribe all things run through all parts and govern all".

After Quesnay gradually accepted Chinese philosophical thoughts, his theory of "natural order" also tended to be perfected. Quesnay officially finalized the "natural order" as the philosophical basis of his entire ideological system and discussed the objective laws of economic development in more detail. In On Natural Rights, Quesnay pointed out that "natural order" was an objective law of natural operation independent of human will. He also included "moral laws" or "moral orders" and "laws of objects" into the category of natural law. He believed that people who formed a society should obey the natural law - the best fundamental rule for governance and the actual law based on natural law - the "rule concerning the management of natural order" (Quesnay, 1980, p. 333). In Le despotisme de la Chine (Despotism in China), Quesnay emphasized the significance of rationality. He believed that only by obtaining the light of rationality through education and the study of nature can legislation compliant with the natural order be formulated, and such supreme legislation should be followed by executive power and the state. Meanwhile, he pointed out that economics itself was developed through the free application of reason: "Only by application based on reason can people develop economic science, and economic science is a great science that lays the foundation for national governance" (Quesnay, 1992, p. 119). That is, Quesnay 
believed that the physiocratic school itself was founded based on his study of natural laws and application of rational induction. Quesnay also derived his thoughts on the national governance model from his observations on the agricultural production of a single farm. According to Quesnay (1992, p. 120), "The management of land farming on a certain farm is a model of extensive national governance, [...] The farmers follow the natural order, so they should only obey the material laws and the conditions set by these material laws, instead of being forced to comply with any other laws. Moreover, the administrative authority should be guided by the material laws and conditions in the rule of the whole society". Hence, Quesnay believed that government governance should follow objective natural laws, similar to farm management.

Chen Daisun (2014, p. 11), one of the economists, contended, "The theory of natural order has expressly confirmed for the first time that there are objective laws in human society independent of people's will and thus proposed the mission of understanding objective laws for economics ... this concept means that the social economy is subject to the constraint of certain objective laws, that categories are interrelated, and that the development of things is theoretically predictable". This thought of Quesnay significantly influenced the subsequent economists. Adam Smith's "invisible hand" actually was still the natural order without feudal appearance. Although Ricardo abandoned the natural order and started with utilitarianism, his system was based entirely on the confirmed existence of the natural law.

\subsection{Analysis of how to grasp the essence of Chinese cultural and economic thoughts from the perspective of Quesnay's thought}

Although Quesnay's economic thought was influenced by Chinese traditional culture, the liberal economic ideas are not necessarily rooted in Chinese traditional culture. Some scholars tried to understand Chinese economic thought in a Western cultural context and academic perspective and deliberately moved closer to Western economics, arguing that there was a liberal economic ideology in Chinese culture, which is unscientific and detrimental. These perceptions are mainly focused on the study of the economic thoughts of Lao Tzu and Sima Qian, which need to be clarified in the Chinese context, so that the true connotations can be revealed accurately.

Lao Tzu, rather than a pure economist, had economic thoughts contained in his Taoist philosophical system. First, from ancient Chinese economic practice guided by Taoism, China has never implemented a Western free-market economic model. The most obvious example was the economic practice in the early Han Dynasty. From the reign of Gao $\mathrm{Zu}$ of Han to the reigns of the Emperors Wen and Jing, they all followed the Huang-Lao theory of "wuwei erzhi (achieving order and equilibrium without ruler's intervention)", which boosted the growth of the social economy remarkably. However, they did not implement total "laissez-faire freedom" economically. Chao Cuo, a high-ranking official in the reigns of the Emperors Wen and Jing, proposed economic policies adopted by both Emperors, such as "emphasis on grains" and "defending the frontier and promoting agriculture". Essentially, the policies were to adjust the grain prices, support the economic status of farmers and achieve balanced economic development across the country through national macro-control and unified organization of production. Second, although legalism based on Taoism had a profound influence on the ancient political and economic system of China, it facilitated the establishment of a unified, centralized political and economic system in China since the Qin and Han dynasties, rather than a Western "small government, big society" system. Han Feizi, a master of legalistic thought, "enjoyed the study of "punishments and their designations' and 'techniques of legal models', but his essentials were rooted in [the teachings of] Huang-Lao" (Sima, 1982, p. 2146) and concretized the Taoist thought of "wuwei", proposing that the monarch should rule the country by law and dispense reward and punishment impartially based on the responsibilities of ministers rather than manage the 
CPE

4,2

194

affairs himself. The First Emperor of Qin and his advisor Li Si applied legalism to the practice of ruling the country and established a unified dynasty. Although the Huang-Lao theory seemed to be the established guiding ideology, the early Han Dynasty was actually deeply influenced by legalists in the actual national governance. As Emperor Xuan of Han said, "We have our own system of governing the country, that is, combining hegemony and benevolent government, rather than educating people by morality only" (Ban, 1962, p. 277), which was an accurate summary of this situation.

Actually, the one-sided understanding of Sima Qian's economic thoughts as "laissez-faire" focused only on some theories in the Records of the Grand Historian: Biography of Merchants, instead of grasping Sima Qian's overall economic thoughts by integrating the whole "Records of the Grand Historian" comprehensively. First, Sima Qian proposed implementing economic control and the policies of a laissez-faire style dialectically in accordance with local conditions rather than emphasizing on laissez-faire only. In The Treatise on the Balanced Standard, Sima Qian pointed out the problems of merchant behaviors and identified the advantages and disadvantages of policies (creating national monopolies for salt and iron and unifying purchase and transportation of goods) implemented by the Emperor Wu of Han dialectically. He argued, "Therefore, when something reaches its zenith, it will start to decline. When a trend reaches its limit, it will shift in the opposite direction. For instance, two opposing trends, opulence and simplicity, alternate over the course of time. This is a change cycle indeed." (Sima, 1982, p. 1442) He believed that economic policies should change with the continuous development of the economic situation. Second, Sima Qian developed the thought of "following the trend" based on Huang-Lao theory. The theory of following the trend is actually about the principle of handling the relationship between subject and object. People should respect and act in accordance with the objective law, which is "following"; under this premise, they should fully mobilize their subjective initiative and make the best of their circumstances to achieve the unity of purpose and regularity, which is "the trend". The thought of "following the trend" has embodied the organic unity between respecting objective laws and exerting people's subjective initiative (Chen, 2009). Sima Qian believed that "following the trend" meant "observing the law and adhering to reasoning", which was similar to the legalistic thoughts such as guiding the country according to the situation and rule of law when extended to economic governance. Third, Sima Qian postulated the inherent maximal goodness of man, which was completely different from the "rational-economic man" hypothesis of Western liberalism. Sima Qian's theory of egoism by nature only referred to the behavior of merchants. According to the whole Records of the Grand Historian, Sima Qian elaborated more about the theory that human nature could be educated and guided in the book. He said, "Ordinances are issued to guide people, and criminal laws to prohibit evil. When ordinances and criminal laws are imperfect, good civilians can still be wary of their behaviors, insist on self-discipline, and obey the law because no officials violate the laws and regulations. Officials who perform their duties and adhere to their disciplines can govern the people effectively. No harsh legal system is required, isn't it?" (Sima, 1982, p. 3099) He believed that laws and ordinances could guide the people to be good. Even when ordinances and criminal laws were imperfect, if officials did not violate the laws or regulations, performed their duties well and followed the etiquette, good civilians would naturally be wary of their behaviors, insist on self-discipline and obey the law. The country would be governed effectively. Essentially, Sima Qian's theory was to reconcrete his own theory of "following the trend", stating that "letting nature take its course" was to guide people with morals and laws in political and economic governance, which was totally different from Western liberalism theory advocating complete individual freedom based on the hypothesis of "rationaleconomic man".

In summary, from the perspective of Taoism and the practice of country governance based on the legalism derived from Taoism, the thoughts of Lao Tzu and Sima Qian are, by no 
means, Western liberalism. In the specific practice of country governance, it is manifested in multiple connotations, including reducing the load of forced labor and lightning the burden of taxes, promoting government thrift, educating people with morals, mitigating the punishment, adjusting economic policies as appropriate based on specific situations, combining national macro-control measures with the policies of a laissez-faire style effectively, strengthening centralization of power and ruling the country by law. Although Quesnay knew the concept of "natural law", he had no idea that legalistic thought also originated from "natural law", which led to his misunderstanding of Chinese philosophy.

\section{Marx's comment and critical inheritance of Quesnay's political economic thought}

2.1 Marx's comment on Quesnay's political economic thought

Marx incisively commented on the duality of Quesnay's political economic system. He pointed out that the great achievement of the physiocratic school founded by Quesnay was that the natural form of production was regarded as a physiological form of society, "that is, a form arising from the natural inevitability of production itself and independent of people's will, policies, etc.", namely the material law; while the error was that "they regard the material law of a particular historical stage of society as an abstract law that also governs all social forms" (Marx, 1972, p. 15).

Marx affirmed the path blazed by physiocrats for developing the modern political economics. He stated that when exploring the natural forms of production, the physiocrats analyzed the material elements by which capital was composed in the labor process, studied the forms that capital took in circulation and specified the connection between the circulation and the reproduction process of capital in general. Regarding these two views, Adam Smith inherited the legacy of the physiocrats and finalized the abstract category. Marx also considered that another contribution and characteristic of the physiocrat school was that it transferred the research on the origin of surplus value from circulation to direct production, thus laying a foundation for the analysis of capitalist production (Marx, 1972, p. 19).

Marx points out that the fundamental contradiction of the physiocratic system lies in the dual interpretation of surplus value. In the physiocrats' view, agricultural labor was the only productive labor, and land rent was the only and general form of surplus value (Marx, 1972, pp. 20-21). On the one hand, the physiocrats were the first ones to try to explain surplus value based on possession of others' labor and such possession in terms of commodity exchange. They stripped off the feudal shell of land ownership from land rent, the actual economic form of land ownership - and attributed it to pure surplus value beyond wages. On the other hand, the physiocrats, simply following the feudal spirit, derived the surplus value from nature rather than society, from land relationship rather than social relationship, from the increase in use value and material rather than value or its increment. Marx scientifically points out that the contradictions in the system of physiocrats are ultimately those in the initial stage of capitalist production. Back then, capitalist production was breaking free from feudal society. Hence, the physiocrats could only explain the feudal society in the context of bourgeoisie for the time being and were yet to identify its own way (Marx, 1972, p. 26). Therefore, Marx concluded (p. 26), "In the conclusions drawn by physiocrats, the superficial admiration of land ownership has become an economic negation of land ownership and affirmation of capitalist production." On the one hand, the physiocrats transferred all taxes to land rent on the ground that land rent was the only surplus value. "This is ostensibly favorable to land ownership, not for the benefit of the industry but for that of land ownership." But on the other hand, "the burden of taxation, and various state interventions, will not fall on the industry, which is thus free from any state intervention" (p. 27). Furthermore, through laissez-faire and unfettered free competition, capitalistic production 
CPE

4,2 can function by itself. From this perspective, the physiocrats actually represented the interests of the emerging bourgeoisie and aspired to liberate bourgeois society from the monarchy established on the ruins of feudal society.

In Marx's opinion, the dual interpretation of surplus value by the physiocratic school founded by Quesnay is interrelated and inseparable. Quesnay started his analysis with the natural form of agricultural production, and the difference between the value of labor capacity and the value created thereby was demonstrated more evidently in the original production sector of agriculture than in any other production sectors, which allowed Quesnay to form his "net product" theory, that is, his theory of surplus value. However, Quesnay failed to analyze surplus value deeply from the perspective of the occupation of others' labor, and instead, in the spirit of feudalism, he derived surplus value from natural relations rather than social ones and regarded it as a natural gift, believing that industry created no value. Hence, the process of giving back the value offered by agriculture to the industry with another equivalent was regarded as a natural process, and the idea of "laissez-faire" was proposed to serve the development of the capitalist industry. In this way, the natural law was transformed into laissez-faire, and the material laws of society at a certain historical stage became abstract laws that governed all social forms. In the final analysis, Quesnay, subject to certain historical limitations in the historical stage of the gradual collapse of the European feudal system and the rise of the bourgeoisie, could not reveal the nature and development laws of the capitalist mode of production movement scientifically and accurately. Quesnay's acceptance and absorption of ancient Chinese philosophy and economic thoughts enriched his economic thought system greatly, but essentially, he still used Chinese thoughts to serve the interests of the emerging bourgeoisie that he represented.

\subsection{Marx's critical inheritance of Quesnay's political economic thought}

Marx critically inherited the research findings of the physiocrats and the theoretical achievements of other classical political economists and created the proletarian political economics that was opposed to bourgeois economics.

First, Quesnay's economic thought was already imprinted by materialism to some extent. In 1758, Quesnay (1980, p. 5) published Questions interessantes sur la population, l'agriculture et le commerce (Interesting Questions on Population, Agriculture, and Commerce), in which he investigated France's climate, land, farming, population and grains for more than a century in detail, laying a foundation for the composition of Tableau économique (Economic Table). In the Tableau économique (Economic Table), Quesnay started with the natural form of agricultural production and summarized capitalist production based on agricultural capitalism. Marxist political economics is a scientific system formed under the dual provisions of historical materialism and dialectical materialism. Through the application of research and narrative methods, Marx discovered the essential relationships and laws of movement of the capitalist economic system through economic phenomena and explained why these essential specifications should take such a form of expression and how it was presented in the form as it appeared to be.

Second, Quesnay analyzed and expounded the status and function of capital in terms of categories, while Adam Smith specified the abstract categories on that basis. Marx standardized a series of economic categories of proletarian political economics scientifically by using the methodology stipulated by historical materialism and materialist dialectics. Marx (1972, p. 15) pointed out that Quesnay understood the economic categories he stipulated under social conditions detached from capitalist production. He believed that due to the nature of social production relations and the changes that occurred in the historical process, economic categories, like production relations he described, rather than permanent being, were also the product of historical relations. 
Third, Marx spoke highly of Quesnay's attempt to explain the reproduction and circulation of total social capital in Tableau économique (Economic Table). Certainly, due to the contradictions and historical limitations of the physiocratic system itself, the reproduction and circulation of social capital described by Quesnay essentially refer to those of production capital, without analyzing the whole reproduction and circulation of industrial capital. To compare with Quesnay, Marx created a complete theory of reproduction and circulation of total social capital based on scientific labor value and surplus value theories to analyze the interacting and interdependent relations between capitalist production and reproduction as well as the contradiction in the commodity circulation and realization process comprehensively. Meanwhile, Marx also completed his own Economic Table under the influence of Quesnay.

Finally, Quesnay put forward the mission of understanding objective laws for economics with his theory of "natural order", blazing a path along which subsequent classical economists advanced. Compared with their predecessors, Marx and Engels expounded the objective laws of the development of human society by establishing historical materialism and revealed the movement law of the capitalist economy based on "overall methodology" from the perspective of historical materialism and two specific methods (research and narrative) stipulated thereof. Marx and Engels also conducted more in-depth research on the development of nature and natural science and discovered the unity of the objective laws of natural social development and those of human social development.

\section{The value of excellent traditional Chinese culture to the development of socialist political economics with Chinese characteristics}

Chinese culture is the vital spiritual line of the Chinese nation and an essential source of the socialist system with Chinese characteristics. One of the reasons that Marxism can be integrated into China is the high inclusiveness of the Chinese excellent traditional culture. According to Zhongyong (The State of Equilibrium and Harmony), "This Equilibrium is the great root (from which grow all the human actings) in the world; and this Harmony is the universal path (in which they should all proceed). Let the State of Equilibrium and Harmony exist in perfection, and heaven and Earth would have their (right) places, (and do their proper work), and all things would be nourished (and flourish)" (Zhu, 1983, p. 18). "Equilibrium" and "Harmony in Diversity" are the core concepts of excellent traditional Chinese culture as well as the lubricant for integrating and coordinating different ethnic groups and religious cultures. The concept of "Equilibrium" emphasizes the complementation, exchange, dialogue, mutual learning and integration of various ethnic cultures and even ideological systems. Thus, the excellent traditional Chinese culture has accepted Marxism with great inclusiveness and allowed Marxism to take root and thrive in China. Second, the values of excellent traditional Chinese culture are interlinked with Marxism. The Li Ji: Li Yun (The Book of Rites: The Conveyance of Rituals), an important ancient Chinese Confucian classic, proposed the thought of shared ideology. The values advocated by shared ideology were essentially compatible with the lofty ideals of communism. Moreover, the concepts of humanism, unity of knowledge and action, practical rationality, yin and yang dialectics embodied in the excellent traditional Chinese culture are also interlinked with Marxist theories. Third, Marxism is chosen by the times, and the Sinicization of Marxism itself is inseparable from the excellent traditional spirit in generations of advanced intellectuals of the Chinese nation. Since the Opium War of 1840, generations of intellectuals have striven to seek the truth of saving the country and people. The Xinhai Revolution that broke out in 1911 led to the overthrow of the Manchu Qing Dynasty and the nominal establishment of a democratic republic in China, just like Western capitalist countries did, but copying the Western-style system did not fundamentally solve the problems of poverty and the grave 
CPE

4,2

198 crisis of mass impoverishment in the country but plunged China into frequent regime changes and incessant fighting among the warlords instead. Afterward, as the October Revolution happened, Marxism-Leninism was introduced to China. It was the sense of responsibility that "every man alive has a duty to his country", the ideal that the world should be equally shared by all, the spirit of constantly striving to be stronger and the aspiration of contributing to the society for the benefit of people, which were unique to advanced Chinese intellectuals, that made Marxism widely spread in China. The outstanding achievements of the Chinese revolution and construction have proved that only Marxism can save and develop China.

General Secretary Xi (2016, pp. 16-17) pointed out, "The resources of excellent traditional Chinese culture are very precious and rare for the development of philosophy and social sciences with Chinese characteristics [...] Cultural self-confidence is a more basic, deeper and more lasting power." After a long history of development, in the journey of realizing the great rejuvenation of the Chinese nation today, the Chinese people should learn from history and draw on the rich experience in the state governance during the course of history and understand the success/failure of the political and economic development of the past dynasties. With adherence to Marxism as our guiding ideology to construct and develop the theoretical system of socialist political economics with Chinese characteristics, more attention should be paid to the knowledge and wisdom accumulated by the Chinese for thousands of years and the intrinsic value of rational speculation; it is also necessary to absorb wisdom and nutrition from the excellent traditional Chinese culture, make the past serve the present, develop the new by weeding through the old so that the socialist political economics with Chinese characteristics can better demonstrate Chinese wisdom, thus providing reliable, scientific and sustainable theoretical support for the construction of the socialist economy with Chinese characteristics in the new era as well as enabling the world to know about "China in academia", "China in theory", "China in philosophy and social sciences", and "China with great contributions to the civilization of mankind" (p. 17).

Socialist political economics with Chinese characteristics is the inheritance and development of Marxist political economics in contemporary China. As General Secretary $\mathrm{Xi}$ stated (2020, p. 120), "After the introduction of Marxism into China, the proposition of scientific socialism was warmly welcomed by the Chinese people, finally took root and blossomed in the land of China, which was not an accident. Instead, it was an outcome of integrating scientific socialism with the excellent historical culture that has been passed down for thousands of years and the values that are unconsciously upheld by the people in their daily lives". In a sense, the success of Marxism in China results from that fact that Marxism has adapted to China's cultural and economic traditions, or more specifically, to China's basic national and actual conditions, that is, it has achieved the unity with China's history, theory and practice. As the "true originator of modern political economics", the ideological system of the physiocratic school founded by Quesnay has accepted and absorbed Chinese culture and philosophical thoughts, further highlighting the significance of traditional Chinese culture and Chinese philosophy. How to explore the relationship of excellent traditional Chinese culture and China's economic theory with Marxist political economics theory at the theoretical level and seek the value of excellent traditional Chinese culture to the development of the socialist political economics with Chinese characteristics has become the mission of the new generation of economists. As General Secretary Xi Jinping said at the National Symposium of Philosophy and Social Sciences, to observe contemporary Chinese philosophy and social sciences, it is required to view from a perspective as broad as the history of the development of the whole world and China. It is undoubtedly a necessary path to explore the development of contemporary Chinese philosophy and social sciences from the interaction between China and global social 
sciences, recognize and contemplate the development of the socialist political economics with Chinese characteristics through the interaction of Oriental and Western thinkers in the history of China and the world.

\section{References}

Ban, G. (1962), Hanshu [The Book of Han], Zhonghua Book Company, Beijing.

Cao, G.H. and Li, L. (1995), "Sima qian jingji sixiang lunli jianlun [A Brief discussion on Sima Qian's economic thought and Ethics]", Zhongguo Renmin Daxue Xuebao [Journal of Renmin University of China], Vol. 9 No. 4, pp. 54-57.

Chen, J.X. (2009), “Cong'Shiji xunli liezhuan’ kan simaqian suoshou huanglaoxue yingxiang [on Sima Qian's influence of Huang-Lao school from officials Biography in the Records of the Grand historian]", Qiusuo [Seeker], Vol. 29 No. 3, pp. 221-223.

Chen, D.S. (2014), Cong Gudian Jingji Xuepai Dao Makesi_Ruogan Zhuyao Xueshuo Fazhan Lunlue [From Classical School of Economics to Marx: A Brief Introduction to the Development of Some Major Doctrines], The Commercial Press, Beijing.

Clarke, J.J. (2011), Dongfang Qimeng: Dongxifang Sixiang de Zaoyu [Oriental Enlightment: The Encounter between Asian and Western Thought], (Chinese translation edition translated by $\mathrm{Yu}$, M. M. and Zeng, X. B.), Shanghai People's Publishing House, Shanghai.

Fu, Y.C. and Yan, P.F. (1995), Ziyou Jingying Haishi Guojia Ganyu [Free Operation or Government Intervention], Economic Science Press, Beijing.

Han, F. (2009), Hanzi Qianjie [A Simple Analysis of Han Feizi's Ideas], Zhonghua Book Company, Beijing.

Hayek, F.A. (1967), Studies in Philosophy, Politics and Economics, The University of Chicago Press, Chicago.

Liu, H. (2017), Yuji Shuxie-Zhongguo Xiandai Sixiangshi Xiezuo Pipan Gangyao [Cross-Writing: Critical Outline of Writing Intellectual History of Modern China], Guangxi Normal University Press, Guilin.

Liu, G., Liao, Z.X. and Liang, H. (2019), "Shichang jingji lilun jiqi zhongguo sixiang suyuan-guofulun yu huozhi leizhuan daodejing bijiao [Market economic theory and its origins in chinese traditional thoughts: a comparison between the wealth of nations and biographies of Merchants \& Tao Te Ching]", Zhongguo Renmin Daxue Xuebao [Journal of the Renmin University of China], Vol. 33 No. 1, pp. 51-63.

Lu, J. (2012), Xinyu Jiaozhu [New Discussions: Collations and Annotations], Zhonghua Book Company, Beijing.

Marx, K. (1971), "From the critical history", Central Compilation and Translation Bureau (Ed.), Makesi engesi quanji: di ershi juan [Marx and Engels Collected Works: Volume 20], (Chinese translation edition translated by Central Compilation and Translation Bureau), People's Publishing House, Beijing, p. 269.

Marx, K. (1972), "The physiocrats", Central Compilation and Translation Bureau (Ed.), Makesi Engesi quanji: di ershiliu juan (diyice) [Marx and Engels Collected Works: Volume 26 (I)], (Chinese translation edition translated by Central Compilation and Translation Bureau), People's Publishing House, Beijing, 15, 19, 20, 21, 23, 26, 27.

Marx, K. (2004), Ziben Lun: Diyijuan [Capital: Volume I], (Chinese Translation Edition Translated by Central Compilation and Translation Bureau), People's Publishing House, Beijing.

Marx, K. (2012), "Production, consumption, distribution, exchange", Central Compilation and Translation Bureau (Ed.), Makesi Engesi Xuanji: Dierjuan [Marx and Engels Selected Works: Volume 2], (Chinese Translation Edition Translated by Central Compilation and Translation Bureau), People's Publishing House, Beijing, p. 705.

Mises, L.V. (1996), Human Action: A Treatise on Economics, Fox \& Wilkes, San Francisco. 
CPE 4,2

Quesnay, F. (1980), Kuinai Jingji Zhuzuo Xuanji [Selected Economic Works of Francois Quesnay], (Chinese Translation Edition Translated by Wu F. D. And Zhang, C. R.), The Commercial Press, Beijing.

Quesnay, F. (1992), Zhonghua Diguo de Zhuanzhi Zhidu [Despotism in China], (Chinese translation edition translated by Tan, M.), The Commercial Press, Beijing.

Reichwein, A. (1962), Shiba Shiji Zhongguo yu Ouzhou Wenhua de Jiechu [China and EuropeIntellectual and Artistic Contacts in the Eighteenth Century], (Chinese translation edition translated by Zhu, J. L.), The Commercial Press, Beijing.

Sima, Q. (1982), Shiji [Records of the Grand Historian], Zhonghua Book Company, Beijing.

Tan, M. (1990), "Zhongnong xuepai jingji xueshuo de zhongguo yuanyuan [The Chinese Origin of Physiocratic Economics]', Jingji Yanjiu [Economic Research Journal], Vol. 25 No. 6, pp. 66-76.

Tang, Q.Z. (2014), Zhongguo Jingji Sixiangshi [History of Chinese Economic Thought], The Commercial Press, Beijing.

The CPC Central Committee and the State Council (2018), "Jiakuai goujian zhongguo tese zhexue shehui kexue [accelerate the construction of philosophy and social sciences with Chinese characteristics]", Literature Research Office of the CPC Central Committee (Ed.), Shibada Yilai Zhongyao Wenxian Xuanbian (Xia) [Selected Important Documents since the Eighteenth CPC National Congress (Vol. 3)], Central Party Literature Press, Beijing, p. 322.

Wang, C. (1990), Lunheng Jiaoshi [Analytical Balance with Collated Elucidations], Zhonghua Book Company, Beijing.

Xi, J.P. (2016), Zai Zhexue Shehui Kexue Gongzuo Zuotan Huishang de Jianghua, Xi Jinping’s Speech at the Symposium on Philosophy and Social Science, People's Publishing House, Beijing.

Xi, J.P. (2020), Xi Jinping Tan Zhiguo Lizheng: Disanjuan [Xi Jinping: The Governance of China: Volume 3], Foreign Languages Press, Beijing.

Zhu, X. (1983), Sishu Zhangju Jizhu [Annotations to Four Books], Zhonghua Book Company, Beijing.

\section{About the authors}

Xu Zhang (1970), male, a native of Laiyang, Shandong, professor and Ph.D. supervisor at the Institute of Economics, Chinese Academy of Social Sciences, mainly engaged in research on the history of economic thoughts, political economy and related issues. Xu Zhang is the corresponding author and can be contacted at: zhangxuphd@vip.163.com

Tianjiao Wang (1989), male, a native of Beijing, Ph.D. candidate at the School of Marxism Studies, Renmin University of China, mainly engaged in research on socialist economic theory and practice.

For instructions on how to order reprints of this article, please visit our website:

www.emeraldgrouppublishing.com/licensing/reprints.htm

Or contact us for further details: permissions@emeraldinsight.com 